\title{
Do Homeowners Associations Mitigate or Aggravate Negative Spillovers from Neighboring Homeowner Distress?
}

\author{
Ron Cheung, Chris Cunningham, and Rachel Meltzer
}

\section{Working Paper 2013-18}

December 2013

\begin{abstract}
Experiences reveal that the monitoring costs of the foreclosure crisis may be nontrivial, and smaller governments may have more success at addressing potential negative externalities. One highly localized form of government is a homeowners association (HOA). HOAs could be well-suited for triaging foreclosures, as they may detect delinquencies and looming defaults through direct observation or missed dues. On the other hand, the reliance on dues may leave H0As particularly vulnerable to members' foreclosure. We examine how property prices respond to homeowner distress and foreclosure within HOA communities in Florida. We combine data sets of HOAs, sales and aggregate loan delinquency, and foreclosures from 2000 through 2008. We find properties in HOAs are relatively less affected by more distressed neighbor homes compared with non-HOA properties, but only when considering less severe delinquency rates. We also find that negative price effects from higher delinquency exposure rates are ameliorated for properties in larger and newer H0As.
\end{abstract}

JEL classification: R00; R21; R31

Key words: associations, foreclosures, delinquency, house prices

The views expressed here are the authors' and not necessarily those of the Federal Reserve Bank of Atlanta or the Federal Reserve System. Any remaining errors are the authors' responsibility.

Please address questions regarding content to Ron Cheung (corresponding author), Oberlin College, Rice Hall 233 , 10 N. Professor Street, Oberlin, OH 44074, 440-775-8971, rcheung@oberlin.edu; Chris Cunningham, Research Department, Federal Reserve Bank of Atlanta, 1000 Peachtree Street, N.E., Atlanta, GA 30309-4470, chris.cunningham@atl.frb.org; or Rachel Meltzer, the Milano School of International Affairs, Management and Urban Policy, the New School, 72 Fifth Avenue, Room 503, New York, NY 10011, meltzerr@newschool.edu.

Federal Reserve Bank of Atlanta working papers, including revised versions, are available on the Atlanta Fed's website at frbatlanta.org/pubs/WP/. Use the WebScriber Service at frbatlanta.org to receive e-mail notifications about new papers. 


\section{Section 1. Introduction}

Scholarly work and popular media have paid great attention to the impact of foreclosures on the housing market; in particular, their effect on the prices of neighboring homes (see, for example, Immergluck and Smith 2006; Leonard and Murdoch 2007; Kobie and Lee 2011; Rogers and Winter 2009; Harding, Rosenblatt, and Yao 2009; Lin, Rosenblatt, and Yao 2009; and Campbell, Giglio, and Pathak 2011). While this research generally finds that proximity of foreclosure negatively affects sales price, there is still some uncertainty as to the causal mechanism. Do foreclosed properties stigmatize a neighborhood, create low comparable sales that affect price bargaining or underwriting, simply increase of the supply of homes for sale, or create a specific disamenity as the delinquent property owner or bank allow the home to languish? It is the concern about this last externality that often drives local governments to secure abandoned homes against squatters, mow lawns or drain swimming pools. ${ }^{1}$ Since the beginning of the foreclosure crisis, 448 cities have enacted Vacant Property Registration Ordinances (VPROs) in an attempt to better monitor foreclosed property and ensure they are properly maintained (Immergluck et. al., 2012). These efforts suggest that the monitoring costs of the foreclosure crisis may be non-trivial and smaller government could have more success at identifying and addressing these potential negative externalities. ${ }^{2}$

One highly localized form of government is a homeowners' association (HOA). Formed to accommodate heterogeneous tastes for public goods, HOAs could be well suited for triaging foreclosures in their communities, as they may detect delinquency and a looming default through direct observation of the property or because the delinquent owner also stops paying dues. By providing landscaping and sanitation services, they may also help prevent negative spillovers to neighbors arising from unmaintained homes. On the other hand, the reliance on dues may leave HOAs particularly vulnerable to members' foreclosures; as more and more members are unable to pay, the burden on remaining homeowners grows. Also, in the event of foreclosure, HOAs are unlikely to recoup past dues because local government claims supersede theirs. In this paper we examine how property prices respond to homeowner distress and foreclosure within HOA communities in Florida. By examining the price spillover of loan delinquency and foreclosure for

\footnotetext{
${ }^{1}$ Jesse McKinley and Malia Wollan, “Skaters Jump In as Foreclosures Drain the Pool”, New York Times December 28, 2008; Alex Klotlowitz, “All Boarded Up”, New York Times Magazine, March 4, 2009.

${ }^{2}$ A study on the distribution of foreclosures across suburban and inner-city communities suggests that a smaller government entity, like an HOA, could be particularly useful for addressing negative spillovers in the suburbs (where non-profits are more sparse, local government is less resourced and where housing is more dispersed in general) (Schildt et. al. 2013).
} 
properties located within the HOA community, compared to properties located outside, we hope to understand whether hyper-local government is more efficacious than traditional cities or towns in responding to a shock. We combine a novel data set of Florida HOAs, sales level data from county assessors and zip-code level measures of loan delinquency and foreclosures from 2000 through 2008.

Results suggest that while properties within an HOA are somewhat more valuable, and zip codes with more HOAs suffer fewer foreclosures, homes within an HOA do not appear to be insulated from the negative effects of extended nearby delinquencies or foreclosures. Only in the case of less severe delinquency rates, do HOA properties appear to be less impacted than non-HOA properties in a statistically significant and economically meaningful way. We find that a one-standard-deviation increase in localized 30-day delinquency lowers HOA property prices by 1.5 percent less than it does non-HOA prices. This initial finding (weakly) suggests that smaller government structures, like HOAs, may shield neighboring properties against some negative spillovers from initial delinquency. Richer specifications suggest that larger HOAs play an important mediating role: negative price effects from higher delinquency exposure rates are further ameliorated for properties that are located in relatively larger and somewhat newer HOAs. This implies that more sophisticated or more resourced HOAs (i.e. the larger ones) are more effective at staving off the negative externalities of nearby distress. The results on age may indicate that newer HOAs may be less subject to the substantial capital expenses that have put older HOAs into financial difficulty and have minimized the ability of HOAs to address distress among their members. Finally, we do not find any positive spillovers from HOAs to neighboring non-HOA property, confirming the prediction that any positively mediating effect is exclusive to the HOA properties.

The paper proceeds as follows. Section 2 gives a brief overview of the growing literature on foreclosures and housing markets. We discuss HOAs and relate their impact to the foreclosure crisis in Section 3. Section 4 introduces the econometric methodology and the data. Section 5 provides the results. Section 6 discusses next steps, offers some policy recommendations and concludes.

\section{Section 2. Foreclosures and the Housing Market}

As the subprime mortgage crisis continues to make its way through the housing market, there has been a large empirical literature on the effects of foreclosures on a range of 
outcomes. In this section, we review some research that has particular relevance to foreclosures' effects on local neighborhoods and communities in which homeowners are likely also to be in contact with homeowners' associations.

Most work in this area takes the form of hedonic studies of house prices. Among the earliest work in this category is that of Immergluck and Smith (2006), who use Chicago data from 1997 and 1998. They find that single-family property values experienced a 0.9 percent decline for each foreclosure within a 1/8-mile radius. Leonard and Murdoch (2009) use sales data and structural and neighborhood characteristics from 2006 in Dallas County, and they find that proximity to foreclosed properties is associated with a lower selling price.

Schuetz, Been and Ellen (2008) use a data set from New York City to estimate a spatial hedonic model of the effects of foreclosure starts (the filing of the foreclosure notice known as the lis pendens) on house prices in the immediate neighborhood. They find evidence of a threshold effect: being near a small number of foreclosures does not depress property values, but past that threshold, additional foreclosures lower home values in a nonlinear fashion. They also show that prices are lower in neighborhoods that would eventually experience foreclosures, suggesting that researchers need to account for the non-random location of foreclosures to avoid bias. The paper has some important differences from our work: the analysis takes place in New York City, with its vastly constrained housing supply, and between 2000 and 2005, before the onset of the housing crisis.

Daneshvary and Clauretie (2012) do use more recent data from the midst of the housing crisis to estimate the effects of foreclosures and short sales on property values in Las Vegas from 2008 to 2009. They find that six months after a foreclosure, neighbors suffer a negative spillover effect of $10 \%$ on their property values. They stress the importance of correcting for market trends, especially in volatile markets, and so their paper is particularly applicable to Florida data.

Recent research has taken advantage of more detailed data and innovative estimation methods. Gerardi et al. (2012), for instance, use repeat sales of single-family houses in the largest fifteen metropolitan statistical areas along with house-level measures of mortgage distress. They are able to observe the precise stage of distress for a home, which includes being seriously delinquent on the mortgage, in foreclosure proceedings and real-estate owned. The authors can therefore account for the fact that the foreclosure externality impacts neighbors before the lender initiates foreclosure. Their model, a modified hedonic, controls for unobserved heterogeneity across parcels using fixed effects at a very fine census block group level. They find that the effects of foreclosures 
on neighboring home prices are fairly small. Houses trade at slightly lower prices when there are homes nearby with delinquent homeowners, when there are homes nearby owned by lenders, and even when there are homes nearby recently sold by lenders in arm's length transactions.

Kobie and Lee (2011) examine the relationship between residential foreclosures and property values with respect to space and time. An innovation in their paper is the spatial definition of a neighbor, which is based on being on the same face block. Unlike straightline distance measurements, the visual nature of a face block allows for focus on the impact of deferred maintenance of homes in the foreclosure process on nearby properties. Using a spatial error model for Cuyahoga County (Cleveland), Ohio, they find that the negative effect of a foreclosure on the sale price doesn't come into play until a year after the foreclosure process begins. They also find that for face blocks with a lot of foreclosures at baseline, the addition of one more foreclosure does not have an impact on the selling price of a nearby property.

Whitaker and Fitzpatrick (2011) and Hartley (2010) incorporate vacancy into their analyses, recognizing that the depressing effect of property values around a foreclosure could be due to both a negative disamenity effect and a housing supply increase effect. Hartley's analysis is based on Chicago home sales between 1998 and 2008. He finds that each single-family foreclosure filing within a 250 -foot radius lowers a property's price by $1.6 \%$; however, in the decomposition analysis, he argues that none of the effect is due to disamenity and the entire effect is the supply expansion effect. However, the decomposition will depend on neighborhood characteristics, in particular the vacancy rate in the area. Whitaker and Fitzpatrick (2011) use data from the Cleveland area to find that the effect of a vacancy or delinquency within 500 feet is a similar 1.4 percent discount. Again, they argue that existing neighborhood vacancy rates play a large part in the net effect, suggesting an important role in foreclosures contributing to housing supply.

In a related paper, Harding, Rosenblatt, and Yao (2009) look at whether the decline in non-distressed property prices is actually due to nearby foreclosures or to a general downward price trend of the whole neighborhood. Harding et al. use repeat-sales data from the FHFA and GSE mortgage loan files covering 1990 to 2007. Their results show that foreclosures can result in a discount to market value of a neighboring property of up to $1 \%$ per nearby foreclosure. This contagion effect also diminishes and becomes insignificant if the foreclosed property is more than 500 feet away. This contagion effect also varies with the phases of foreclosure and time. The greatest discount in sales prices seems to occur between the foreclosure sale and the REO sale. Also, the discount to neighboring property values is negligible for the first year after a foreclosure filling. 
Therefore, the authors suggest that policy makers should aim to put in place policy to speed up the process so that foreclosure is completed within a year.

Most closely related to our paper is a study by Fisher et al. (2013) that looks at price effects of foreclosures within condominium developments in Boston. They use a very detailed dataset of condominium sales transactions for the years 1987-2011 to test whether nearby foreclosures depress sales prices via the "supply effect" or an investment externality. They not only compare prices for properties in distinct condominium associations, but they also compare prices within associations (but at different locations). This allows them to identify different mechanisms behind any negative foreclosure price effects. They find that condo units sell at a 2.4 average discount when a foreclosure shares the same address (and this effect is much stronger in smaller, often single-address, associations); there is no price differential when a foreclosure is in the same condo association, but different address, or in a different association entirely. Together, they argue that this supports investment externalities as the driving force behind foreclosurerelated price effects. Our analysis differs in its focus on single-family homeowners associations (versus multifamily condos) in Florida, one of the hardest hit states with respect to housing distress and foreclosures. In addition, while our data does not allow us to identify price effects as precisely, we do have much more variation in the age and size of the associations.

\section{Section 3. HOAs and Their Role in the Foreclosure Crisis}

\section{The Origins of HOAs}

HOAs, and Residential Community Associations (RCAs) more broadly, are considered a type of "private government" that form due to property owner dissatisfaction with public government services (Helsley and Strange 1998). More generally, HOAs, and other private governments, are a mechanism for addressing heterogeneity in demand for services at a very localized level. Members will pay into the private governments if they value, and are willing to pay for, services above and beyond those provided by the local public sector. HOAs are one type of RCA (a term that includes both cooperative and condominium associations as well), and are often considered synonymous with planned unit developments (PUDs) and gated communities. The developer typically establishes the association upon erecting the community and then allocates the shares of the association as he or she sells the units in the development. HOAs are ultimately incorporated as non-profits and homeowners in the community share ownership of the 
common areas and facilities. The association also establishes and enforces covenants and restrictions governing land use (Cheung 2008; Cheung and Meltzer 2013). Each member pays an assessment (or fee) to maintain the amenities and to provide other supplemental services to the community. Therefore, the member homes are linked both financially and physically.

During the past few decades HOAs have proliferated across the country as one of the fastest growing housing options and privatization efforts (McCabe and Tao 2006). In 1962 there were roughly 500 RCAs nationally, and that number rose to more than 280,000 by 2007 (Gordon 2004; CAI 2008). CAI also estimates that, as of 2000, nearly $60 \%$ of all new construction was included as part of an RCA (CAI 2000). By 2007 the number of units in some kind of RCA constituted nearly 20 percent of the national housing stock. The boom in HOAs has been particularly evident in states like Florida, the context for our analysis. The first recorded HOA in Florida was established in 1959, and since 1990, the number of HOAs has increased by nearly $140 \%$ percent. Not only has Florida witnessed an unprecedented growth in HOAs, but it has been hit particularly hard by the recent foreclosure crisis: the state has one quarter of the nation's foreclosures. ${ }^{3}$

\section{HOAs and the Foreclosure Crisis}

There are a number of reasons why HOAs could mediate the effect of neighboring loan delinquencies and foreclosures on prices. First, an important reason why homeowners buy into HOAs is the (perceived) stability in property values that they provide. Many HOAs provide public services, such as street cleaning and yard maintenance, that can limit the visual blight associated with some foreclosures. They are also a smaller, and perhaps more responsive, form of private government that can coordinate additional security in the case of abandoned properties. In these ways, HOAs may stave off the negative externality effects of a foreclosure on neighboring property values.

Alternatively, HOAs, and the public goods they provide, may be particularly vulnerable to non-payments associated with foreclosure. Lush (2011) cites a survey by the Community Association Institute, that “of the nation's 300,000 homeowners”, associations, more than $50 \%$ now face 'serious financial problems." " Do the negative effects of spillovers manifest themselves "more negatively" for properties within HOAs, suggesting that properties in HOAs are bearing the added burden of supporting

\footnotetext{
${ }^{3}$ Lizette Alvarez, “Florida Weighs a Measure to Ease Way to Foreclosure”, New York Times February 22, 2012.
} 
delinquent members? Homeowner distress has brought a number of HOAs to financial ruin, as many HOAs could no longer count on timely payment of assessments. As assessments fund the common facilities and maintenance, the deterioration associated with distressed homeowners may weaken the collective action made possible by the HOA.

Popular press has highlighted the neighbor-versus-neighbor legal action that is sometimes engendered by the tensions in HOA budgets. Wade Goodwyn, a reporter for National Public Radio, quotes a state representative from Texas who is trying to pass HOA reform legislation, "HOA board members and advocates testify and say, 'We need the power to access and fine and foreclose, and we need the money. And we look for people in violation of the rules and restrictions that we put in place. And they drive around in golf carts looking for them'” (Goodwyn, 2012). This quotation also highlights an added complication to the foreclosure issue - HOAs themselves have the ability to initiate foreclosure proceedings on delinquent homeowners. Nonpayment of assessments (and even fines, in some localities) constitutes grounds for an HOA to place a lien on a property. The number of HOA-initiated foreclosures is small, compared to the extent of the foreclosure crisis, but they are becoming more common. ${ }^{4}$ The financial fragility currently experienced by HOAs, particularly in areas hard hit by the housing crisis, contributes to house price uncertainty and possible depreciation, which could offset any advantage they have in triaging foreclosure.

A simple graphic shows specifically that HOAs and delinquency are connected. Figure 1 plots the share of the zip code that is in some HOA against the share of homes that are seriously delinquent, defined as 90 days or more. We see a slight positive relationship, which may suggest that HOAs, being located in places with more distressed homes, may be a key factor in staving or exacerbating the price declines associated with delinquency.

Of course, both of these channels may simply be indicating that HOAs tend to locate in areas that are experiencing the most rapid price declines and the most delinquencies. To explore the causal relationship, we turn to our econometric model.

\section{Section 4. Data and Empirical Strategy}

\footnotetext{
${ }^{4}$ For instance, Nguyen (2011) states that in 2010, HOAs foreclosed on only about 300 Bay Area homes. However, this was twice as many as five years previously. Lush (2011) states the number of associationinitiated foreclosures in Houston jumped from 500 in 1995 to 2200 in 2007.
} 
This analysis furthers the line of research looking into the negative spillover effects of foreclosures, and intersects it with the growing literature on the role of HOAs in local service and housing provision. In order to test the above hypotheses we combine several novel data sources. We use a comprehensive database of HOAs for the entire state of Florida as of 2008 and map them, at a residential parcel level. ${ }^{5}$ This parcel level data is then linked to property tax records of sales price and date, as well as parcel characteristics compiled by the county assessors. With this dataset we are able to determine if a parcel lies within an HOA, as well as the age and size of the HOA. Our sample consists of all arms'-length sales in the state from 2000 to 2008.

To construct the dataset, we obtained a list of HOAs from Sunshine List, a private, Florida-based corporation that has compiled the most comprehensive and up-to-date list of HOAs in the state. We observe the creation date of every active HOA in Florida as of 2008 (the first HOA was incorporated in 1959), as well as the address of the officers of each association. We geocode, using geographic information system (GIS) software, the reported addresses of the officers onto an electronic parcel map of the state obtained from the Florida Department of Revenue.

To identify the HOA boundaries, we make the assumption that all parcels within the same subdivision of the officers of the HOAs lie in the same HOA. By counting the number of residential parcels in the subdivision, we can obtain the number of housing units in the HOA. Our result is the most comprehensive geographic file of HOA activity that we know of, covering virtually the entire state of Florida.

We also obtain databases of securitized mortgages maintained by CoreLogic and Loan Performance. The CoreLogic database consists of mortgages that were issued as part of a private label mortgage back security and thus contains most of the loans that are associated with subprime originators (and thus a large majority of distressed loans from 2000 through 2009). Loan Performance, on the other hand, tracks mortgages guaranteed by the GSEs and is thus comprised mostly of conventional loans.

As we do not know the addresses of individual delinquencies, we match properties to zip codes and calculate the rate of delinquency of securitized mortgages within a given zip code and month. For comparability across different lengths of delinquency, we normalize the rates for the econometric specifications. This represents, to our knowledge, the first comprehensive measure of delinquency at the zip code level for Florida, yet it still does not include the universe of servicers nor any mortgages held in a bank's portfolio. We

\footnotetext{
${ }^{5}$ For more information on this HOA dataset and its construction, please see Cheung and Meltzer (2013) and Meltzer and Cheung (2013).
} 
principally rely on the delinquency measures over actual foreclosure for three reasons. ${ }^{6}$ First, work by Gerardi et al. (2012) suggests that the greatest negative externality may occur before foreclosure actually occurs. Second, banks may choose to delay foreclosure if they lack sufficient capacity or documentation to pursue it, if they wish to avoid recognizing the loss on their balance sheet or if they do not believe they will recover much from foreclosure. Thus, the decision to foreclose may be endogenous with respect to house prices in an area.

\section{Threats to Identification}

Two aspects about our data may pose potential threats to identifying the causal effect of HOA prevalence on the foreclosure disamenity. First, because we only have zip code measures of delinquency, we cannot precisely identify whether a borrower is delinquent in a parcel within or outside the boundaries of an HOA. If the delinquencies are chiefly occurring in the same HOA as the parcel, we have identified the exacerbation/mitigation effect - namely, the effect of an HOA to address foreclosure externalities within its boundaries. However, to the extent that delinquencies lie within the zip code but outside the HOA, our estimates could be biased (i.e. we would be observing a more intense HOA effect than actually exists). As HOAs (and subdivisions in general) are often separated from each other by roads, green space or even a gate, the ability of an HOA to address the negative spillover effects of a foreclosure may be more limited if it occurs outside the HOA.

Given the limitations of our delinquency data, we address this obstacle by constructing and including in the regression a measure of HOA prevalence in the zip code in order to compensate for the fact that we cannot precisely identify delinquent parcels as HOA members. This variable is meant to control for the share of HOA parcels in the zip code, with the assumption that for zip codes with higher HOA shares, the likelihood of any parcel (and in particular a delinquent one) being in an HOA is higher as well. This test will help to confirm whether or not we are picking up a within HOA (versus simply within ZIP code) effect. ${ }^{7}$

\footnotetext{
${ }^{6}$ We include both in our analysis, for comparison's sake.

${ }^{7}$ We also stratify the sample by the share of HOA parcels in the zip code to check whether the HOA effect is persistent for sub-samples with higher (as compared to lower) shares of HOA parcels. We find that generally, the coefficient on the interaction term of HOA and delinquency has the greatest magnitude for the quartile of zip codes that have the lowest shares of HOA parcels. However, there is no statistically significant difference between different quantiles in their delinquency mitigation. .
} 
We also include in the model a measure of HOA size for each individual parcel that resides in an HOA. This will further give us a sense of whether any exacerbation/mitigation is taking place within the HOA (as opposed to across them). The larger the HOA, the more likely the delinquencies reside inside that parcel's host HOA; therefore the coefficient on this variable will give us a sense of the differential between the within-HOA and overall HOA effect.

The second potential threat to identification is the reverse causality between house prices and delinquency. In our framework, delinquency and homeowner distress induce house prices to fall in surrounding properties. However, the falling prices could then induce more homeowners to enter delinquency. If this reverse causality affected HOA members more than non-HOA members - for instance, if unpaid HOA fees led to more delinquency filings - then estimates for the impact of HOAs would be biased downward. Given that anecdotal evidence suggests that HOAs are increasingly pursuing foreclosure in response to budgetary shortfalls, this source of endogeneity may be present. To the extent that falling house prices are part of a broader trend, our geographic fixed effects (county-year / zip code / municipality) will absorb differences that make some areas (and years, in the case of the county-year fixed effects) more prone to house price declines. While this is an imperfect way to address endogeneity, we believe that the overall findings of the paper are consistent, given that the direction of the bias implies that whatever mitigation or exacerbation effect we find for HOAs may be considered a lower bound.

\section{Baseline}

We start with a standard hedonic regression model to predict the sales price of property $i$ at time $t$. We then incorporate information on the extent of localized delinquency rates; specifically, we explore whether or not a higher incidence of mortgages with 30-day, 60day, 90+-day loan payment delinquencies in the immediate area (measured by the zip code) affects a property's value. We also identify properties that are in active foreclosure and test for a differential effect from their concentrated incidence. We run separate models for each of these distress measures, and display them side-by-side to demonstrate any progression in the effect. We then incorporate the HOA data and ask whether this effect is different for parcels inside HOAs (as compared to non-HOA parcels in the same zip code). Our baseline regression model takes the following form:

$\ln \mathrm{P}_{\mathrm{it}}=\beta_{0}+\beta_{1}\left(\mathbf{X}_{\mathrm{it}}\right)+\beta_{2}\left(\right.$ Delinq $\left._{\mathrm{zt}}\right)+\beta_{3}\left(\mathbf{H O A}_{\mathrm{it}}\right)+\beta_{4}\left(\mathbf{H O A}_{\mathrm{it}} *\right.$ Delinq $\left._{\mathrm{zt}}\right)+\beta_{5}($ Share of Zip Code in $\mathrm{HOA})+\mathrm{d}_{\mathrm{c}, \mathrm{t}}+\varepsilon_{\text {it }}$ 
Where $\mathrm{P}_{\mathrm{it}}$ represents the real sales price (2008 dollars) for a property $i$ at time $t$; $\mathrm{X}_{\mathrm{it}}$ is a vector of property characteristics for property $i$ at time $t$; Delinq $q_{z t}$ includes the share of mortgages delinquent in zip code $z$ at time $t$; and $\mathbf{H O A}_{\text {it }}$ is a vector of HOA variables. All standard errors are clustered by zip code.

Before moving to the key HOA and delinquency variables, we describe some of the controls. The vector of property characteristics $\mathrm{X}_{\mathrm{it}}$ comes from the property assessors' tax rolls, and their accuracy is verified periodically through on-site inspections. They include:

- Lot size, in square feet;

- "Quality of improvement,” an assessor-determined level of the construction quality of the housing unit, ranging from "minimum” to "superior";

- Year built;

- Total living area, in square feet;

- Number of housing units in property;

- Indicator for vacant;

- Indicator for single-family.

Moving to the delinquency measure, we use four different measures of delinquency in Delinq $\mathrm{zt}_{\mathrm{z}}$ : 30 days delinquency rate; 60 days delinquency rate; 90 days delinquency rate; in foreclosure rate. ${ }^{8}$ The standard explanation for a negative foreclosure externality suggests that the $\beta_{2}$ coefficient should be negative for each of these.

The baseline regression has one HOA-related variable, $H O A_{i t}$, which takes on the value of 1 if a parcel is in an HOA at time $t$ and 0 otherwise; the coefficient on this variable can be interpreted as the difference in price between HOA and non-HOA parcels. Based on research from capitalization studies such as Meltzer and Cheung (2013), we expect the sign of $\beta_{3}$ to be positive, indicating an HOA premium.

The key parameter to be estimated is $\beta_{4}$, in front of the interaction term $\left(\mathbf{H O A}_{\mathrm{it}}{ }^{*}\right.$ Delinq $\left.\mathrm{z}_{\mathrm{zt}}\right)$. This is the extent to which HOA membership can mitigate (positive $\beta_{4}$ ) or exacerbate (negative $\beta_{4}$ ) delinquency externalities in the area. It can be interpreted in the following way: "for each additional delinquency or foreclosure in the same zip code as parcel $i$, HOA membership decreases/increases the negative spillover effect.”

\footnotetext{
${ }^{8}$ Throughout the paper, "30 days delinquent" refers to properties that are more than 30 days late but less than 60; "60 days delinquent" refers to properties that are more than 60 days late but less than 90 ; "90 days delinquent” refers to properties more than 90 days late but for which foreclosure proceedings have not been initiated yet. Thus, the rates will be mutually exclusive. We discuss our reasons for the definition of the rate in this way in the next section of the paper.
} 
As was discussed in the last section, we use two additional controls to address any threats to identification. First, for each parcel, we control for the HOA membership rate for parcels within the same zip code. This will help us control for the likelihood of a delinquency occurring within an HOA. Second, we include a set of $\mathrm{d}_{\mathrm{ct}}$, county-year fixed effects to control for unobserved heterogeneity across counties over time. ${ }^{9}$ By controlling for differences in local housing markets, these fixed effects also help address the potential reverse causality problem.

\section{Variations}

In order to better understand the nature of the HOA-delinquency interaction, we augment the baseline model to include various HOA characteristics to test for some of the mechanisms discussed in Section 3. The augmented model generally takes the same form as above, but now includes additional HOA-relevant variables in the $\mathbf{H O A}_{\text {it }}$ and HOA $_{\text {it }}{ }^{*}$ Delinq $q_{\mathrm{zt}}$ vectors. We are limited by the information made available in the data, and therefore make some reasonable assumptions to carry out the empirical tests.

First, we test for a differential mediating effect between relatively older and newer HOAs. To do this, we include a continuous linear trend variable, HOA age, which captures the price trend of HOA parcels after HOA formation, relative to non-HOA properties on average. We also interact delinquency/foreclosure rates with this continuous measure of time since HOA formation, which allows the HOA effect to linearly vary over time. We believe the age of the HOA might matter for its capacity to manage the effects of localized delinquency or foreclosure. For example, newer HOAs likely have smaller reserves and less of a cushion to withstand the financial hit of foregone fees. Older HOAs may also be comprised of more well-acquainted members who are more likely to come together and mitigate the negative effects of delinquencies; these older HOAs may also be more "well-oiled” and prepared to manage and pre-empt any detrimental repercussions.

Second, we test for different effects across HOAs of varying sizes by including HOA size (specifically, the number of parcels in that particular HOA). We also interact the delinquency variables with this measure of HOA size. We propose that HOA size will capture the level of intimacy among the members and that smaller HOAs could positively

\footnotetext{
${ }^{9}$ We replicate the regressions using zip code fixed effects and city fixed effects to control for more localized neighborhood heterogeneity, and the results are substantively the same. We opt for the lesscontrolled model to avoid absorbing too much variation in the delinquency measures and to ease the burden of calculation. In the Appendix tables A1 and A2, we provide the estimated coefficients for the three main independent variables of the analysis using these alternative fixed effects.
} 
mediate the delinquency effect by jumping in to help distressed homeowners earlier in the process. On the other hand, larger HOAs might also be more sophisticated and have the technology (and enforcement) to stem delinquency earlier in the process.

Finally, we conduct two analyses to check the robustness of the previous specifications. First, we include in the regression an indicator for non-HOA properties located within a 2-mile radius outside any HOA border and interact it with the delinquency measures. This is intended to capture any spillover effect from the HOA; presumably, properties located outside of the HOA (and therefore outside their jurisdiction) should not benefit from, and possibly suffer from a lack of, any mediating HOA effect. On the other hand, non-HOA properties in relative proximity of an HOA might benefit from the HOAs' collective mitigation efforts, should the neighboring, blighted non-member house pose a threat to HOA property values. This test will identify the spatial extent of any mediating HOA effect on housing distress.

\section{Section 5. Results}

\section{Summary statistics}

We first summarize the characteristics of HOA and non-HOA parcels in our sample; these are displayed in Table 1. The sample has 316,267 home sales between January 2000 and December 2008. The statistics show some differences between HOA and nonHOA properties, as shown by t-tests of the differences in means. HOA properties tend to sell at higher prices, and they also tend to be bigger (in terms of living area) than nonHOA properties (but have smaller lots). The HOA properties also have more variation along these lines. HOA properties are, on average, newer (both in terms of mean and spread) and also tend to be comprised of more single-family homes (versus multi-family condominiums). ${ }^{10}$ This is not surprising, given the more recent boom in planned developments and gated communities that are often governed by an HOA and populated by single family homes.

The table presents measures of housing distress. The average ZIP code in the overall sample has a 30-day (pre-normalized) delinquency rate of .09; this is about the same as for the neighborhoods in which non-HOA properties reside (and the ZIP code rate for

\footnotetext{
${ }^{10}$ The sample, however, is overwhelmingly comprised of single family homes; the condo portion makes up less than five percent.
} 
HOA properties is slightly lower at .061). The average ZIP code delinquency rates go up as the duration of delinquency extends, but dip at the foreclosure stage. Neighborhood delinquency rates generally stay lower for HOA properties compared to non-HOA properties. This difference is largest for properties surrounded by homes in delinquency for more than 90 days. These statistics suggest that any stark differences in price outcomes for HOA and non-HOA properties will most likely take place in the context of relatively more delinquent neighboring properties.

About 19 percent of the sample properties reside in an HOA and the average HOA size is 421 units. As the maps in Figure 2 illustrate, HOAs have primarily emerged along the coasts, and increasingly in the central peninsula and pockets of the northern panhandle. As expected, they are most prevalent in the central and suburban parts of the state, where developable land is abundant. The number of HOAs in a particular jurisdiction varies considerably; as of 2008, some places had only one HOA while others had 300 or more. In practice, HOAs are more common in the unincorporated portions of the county than in municipalities; Orlando, for example, has 139 HOAs, while Orange County has 424. The HOA share variable (displayed in Table 1) also indicates that HOA properties (as compared to non-HOA ones) tend to locate in zip codes with relatively more HOA properties overall (a share of 22 percent versus 12.3\%).

\section{Baseline results}

To begin, we estimate a hedonic regression including only the delinquency rate in order to obtain a baseline understanding of how neighborhood circumstances of homeowner distress affect prices (displayed in Table 2). We present results for the rate of loans that are 30 days delinquent, but note that the results on the housing and neighborhood characteristic regressors are substantively similar when we use rates based on longer delinquency thresholds. The main advantage of the 30 day measure is that it measures the flow into the delinquent state. Thus, it better reflects the moment of initial homeowner distress, as that is the stage at which the property value decline mitigation power of the HOA is most likely, whereas 60-, 90- days delinquent and in foreclosure represent more of the stock of distressed properties in the zip code and can vary based on judicial processes and bank expedience. $^{11}$

\footnotetext{
${ }^{11}$ A referee expressed concern that the 30-day delinquency rate may not be a meaningful measure of the percentage of homeowners entering initial housing distress if many of homeowners who are between 30 and 60 days delinquent leave delinquency shortly. This may occur, for instance, if homeowners miss a mortgage payment due to a one-time mistake, or if the mortgager accidentally neglects to record a payment. To explore this potential complication, we recalculate the 30-day delinquency rate for each zip code, with the additional restriction that the 30-day delinquency eventually becomes a 90-day delinquency or a
} 
As expected, the sign on the coefficient is negative and highly significant; as delinquency rates in the surrounding neighborhood rise, housing prices on average decline. In the next column of Table 2 we show results of a hedonic regression including only the HOA variable in order to obtain a baseline picture of how HOA membership affects price. The coefficient is positive and highly significant, indicating a price premium for properties located inside an HOA. It is important to point out that the coefficient on the HOA share variable is consistently negative, but insignificant; this suggests that the neighborhood prevalence of HOAs is not driving price differentials. ${ }^{12}$

We also note that the signs of the hedonics are consistent with expectations: properties that are newer, bigger, improved (rather than vacant), and single-family (rather than condominium) sell for higher prices. All of these effects remain unchanged when the delinquency and HOA variables are both included in the same regression (see the third column of Table 2). Therefore, the price effects of neighboring homeowner delinquency and HOA membership are opposite.

In Column 3 of Table 2 we also present the effect of the 30 day delinquency interacted with HOA status and find that a one-standard deviation increase in delinquency in the zip code lowers the value of HOA homes by 1.5 percentage points less than it does for nonHOA properties. This effect is statistically significant at the seven percent level.

In Table 3 we display the results from regressions that test for the interaction between HOA membership and neighborhood homeowner distress. For all of the remaining regressions we run four models to test for various delinquency thresholds: 30-days delinquent, 60-days delinquent, more than 90-days delinquent and active foreclosure. This will reveal any variation in impact at different stages of distress. ${ }^{13}$

First, the sign and significance of the delinquency rate and $H O A$ coefficients generally reflect those discussed above. The interaction between $H O A$ and delinquency rate is positive and statistically significant only at the 30-days delinquent level, but only at the $10 \%$ level of significance. In sum, HOA membership appears to have no significant (and at most a weak positive) mediating effect on prices of homes situated near higher rates of

foreclosure within the year. The correlation between this restricted rate and the rate that we use in the analysis is 0.97 . When we use the alternative measure in the specification presented in column 3 of Table 2, the coefficient estimate is slightly larger, 0.17 vs. 0.15 and statistically different from zero at the 5 percent level.

${ }^{12}$ When we exclude this variable from the regression, the coefficients on the parcel-level HOA variables do not change dramatically (in terms of magnitude, sign and significance). These results are consistent across all specifications and are only highlighted here.

${ }^{13}$ The coefficients for the side-by-side models are standardized so that any effects can be compared across delinquency specifications. 
mortgage delinquencies. The positive remediation afforded by HOAs occurs only in the early stages of delinquency. This suggests that the benefits of HOAs' uniformity and services have limited success in hiding the problems of foreclosure, at least for a short while. As properties get extremely distressed, however, HOAs are not able to counteract the negative externality posed by homeowner distress.

\section{Variations in HOA characteristics}

We now present results from regressions that exploit available information on HOA characteristics to better understand the nature of the above-referenced interaction. These results are displayed in Tables 4 to 6 . First, we augment the baseline model by including a set of variables to capture the age of the HOA. We create a dummy variable for whether a property is located in an HOA that is less than five years old or in an HOA that is five to fifteen years old. ${ }^{14}$ We interact this age dummy with the delinquency rate variable. The left out age category, therefore, is an HOA that is more than fifteen years old.

The results are shown in Table 4. Overall, age does seem to matter. The omitted age category is HOAs over 15 years old. We find that relative to this group, HOAs less than five years old are associated with an ameliorating effect on the delinquency externality. Indeed, the magnitude of the coefficient is nearly the same as the age-free (HOA*delinquency) interaction. This suggests that while HOAs in general help to mitigate the negative externality associated with 30-day delinquency, those properties in young HOAs enjoy a benefit twice as large.

We posit that one possible reason why younger HOAs may be better able to weather localized housing distress is that they may be related to the type of expenditures on which HOAs spend their budgets. In younger HOAs, they are more likely to be on services; while in older HOAs, they are more likely to be on capital and on repairing aging infrastructure. Delinquent HOA fees will possibly lead to a more visible deterioration of common facilities in older HOAs, which are already worn from age.

Second, we add to the baseline model a variable, HOA size, which measures the size of the HOA, or more specifically, the number of parcels in the HOA subdivision(s). As above, this variable is entered alone and as an interaction with all four delinquency measures.

\footnotetext{
${ }^{14}$ We repeat this model with a continuous, linear measure of HOA age and the results are substantively consistent. These results are available from the authors upon request.
} 
The results are displayed in Table 5, and size does seem to matter. While being in an HOA carries a premium, if that HOA is relatively larger, it, on average, devalues the home. However, a larger HOA positively mediates the effect of neighborhood housing distress: the interaction term between $H O A$ size and the delinquency rate is generally positive and highly significant. In terms of magnitude, a one standard deviation increase in the HOA size will reduce the delinquency externality by an extra 2.7 percentage points. $^{15}$

In addition, the ameliorating effect seems most pronounced earlier in the process, i.e. when delinquency rates are less persistent. These results suggest that larger, perhaps more sophisticated and or more resourced, HOAs are more effective at staving off the negative externalities of nearby distress. ${ }^{16}$ They may either have systems in place to stem physical or financial deterioration or large enough reserves to provide a financial cushion in the face of foregone fees and other costs. ${ }^{17}$

Finally, we create a dummy variable, HOA spillover, which takes on the value of 1 if a non-HOA property is within 2 miles of an HOA border, and 0 otherwise. We include this variable in the baseline regression and also interact it with the delinquency rate to capture any mediating HOA effects that spill across the HOA border.

Table 6 indicates that while the interaction term is generally negative, most of the coefficients are statistically insignificant. The sole exception is in the 60-day delinquency specification, which provides some evidence that HOAs are not fully mediating the negative externalities associated with localized homeowner distress. However, these results generally reinforce the HOA effect, which is positive relative to non-HOA properties, and consistent with the expectation that any mediating effect would be strongest within the association's jurisdictional boundaries.

\footnotetext{
${ }^{15}$ The standard deviation of HOA size is 700 . Multiplying by the coefficient on (HOA size * delinquency) gives 0.027 .

${ }^{16}$ A referee expressed concern that the size of HOA is potentially a poor measure of capacity, as a large HOA does not necessarily mean an increased ability to engage in effective mitigation. Ideally, we would have access to the budgets of the HOAs, so we know how much spending is targeted toward delinquent homes. This data would be practically impossible to obtain, and so as a robustness check, we added in the "median value of properties in the HOA over 2000-2002" as a control variable to proxy for the wealth of the HOA. We use pre-crisis values to avoid endogeneity issues, and we make the imperfect assumption that median value is correlated with HOA budgets. We do not find any substantive changes to our HOA coefficients. Regression results are available from the authors.

${ }^{17}$ This finding could also indicate that the within-HOA effect is slightly less intense than the overall HOA effect, because the likelihood that delinquencies will reside in the same HOA as the transacting parcel is greater in a larger HOA. As mentioned earlier in the paper, this serves as a robustness check against any threats to identification.
} 


\section{Section 6. Conclusions and Policy Implications}

One of the stronger cases for private government (or specifically HOAs) is that they can be more responsive to their constituents. Yet in the wake of an unprecedented foreclosure and housing market crisis, evidence for their efficacy remains mixed. Leading up to this recession, the housing market was subject to the proliferation of HOAs, and this paper addresses whether or not these associations have exacerbated or tempered any negative housing price effects. While many argue that HOAs are a "market-driven” mechanism that merely responds to local demand for housing location and amenities (McKenzie 2003; Strahilevitz 2005), they are often endorsed, both explicitly and implicitly, by local and state governments. Even though HOAs are privately operated, they can produce externalities that have broader public implications. Our paper provides insight into the role of HOAs, and by extension other cooperative housing arrangements, in the duration and spread of housing distress.

Results suggest that the property values for HOA homes are less vulnerable to negative price externalities from neighboring distressed homes, compared to those for non-HOA homes. However, only in one case is this effect statistically significant and economically meaningful. We find that a one-standard-deviation increase in 30-day delinquency increases prices in an HOA by an additional 1.5 percent.

Additional results indicate that HOA size plays an important mediating role: negative price effects from higher delinquency exposure rates are ameliorated for properties that are located in relatively larger HOAs. This implies that larger, perhaps more sophisticated or more resourced, HOAs are more effective at staving off the negative externalities of nearby distress. Younger HOAs seem to have a positive mediating effect on price, compared to HOAs over 15 years old. Tests for spillover effects come up mainly insignificant, suggesting that any mediating effect is exclusive to the HOA properties.

Private governments, like HOAs, have received mixed reviews. There is evidence to suggest that these associations can exacerbate residential segregation (Meltzer 2013) and (empirically unsubstantiated) prevailing opinion presumes that they encourage a withdrawal from public civic engagement (Gordon 2003). On the other hand, local governments often promote the formation of such associations since they can potentially offload service responsibilities onto them (Cheung 2008); this can be particularly appealing during times of fiscal stress. Our findings suggest that private governments can also play a particularly distinctive, and potentially helpful, role in situations of concentrated housing (or, more generally, neighborhood) distress. Specifically, local governments can consider coordinating with larger HOAs that have the capacity to monitor and intervene at the property or neighborhood level; our results indicate that 
these are instances where the private government may have more localized information that could assist with broader public foreclosure remediation (and prevention) efforts.

The fiscal and physical implications for local municipalities are meaningful. Since HOAs, and other forms of private government, operate off of membership fees, the explicit costs to local government are minimal (at most). We do not have information on whether or not the public sector was encouraging HOAs to monitor their member homes in the face of localized distress, but the assumption is that any action on the part of the HOA is primarily driven by self-preservation. This suggests that if local municipalities can actively interact with the neighborhood associations in prevention and remediation efforts then the damage to the local fisc and built environment could potentially be mitigated in a meaningful way.

\section{Acknowledgements}

We thank the Lincoln Institute of Land Policy for financially supporting this project. We gratefully acknowledge the research assistance of Saksham Khosla and Prakash Paudel at Oberlin College, and Ronnie Hutchinson at the Furman Center at NYU. All errors and omissions are our own. 


\section{Works Cited}

Campbell, John Y, Stefano Giglio, and Parag Pathak. 2011. "Forced Sales and House Prices.” American Economic Review, 101(5): 2108 - 2131.

Cheung, Ron. 2008. "The Interaction Between Public and Private Governments: An Empirical Analysis.” Journal of Urban Economics, 63(3): 885-901.

Cheung, Ron and Rachel Meltzer. 2013. “Homeowners Associations and the Demand for Local Land Use Regulation.” Journal of Regional Science, 53(3): 511-534.

Community Associations Institute (CAI). 2000. Community Associations Factbook. Alexandria, VA: Community Associations Institute.

Community Associations Institute (CAI). 2008. Industry Data: National Statistics. Available at http://www.caionline.org/about/facts.cfm.

Daneshvary, Nasser, and Terrence M. Clauretie. 2012. “Toxic Neighbors: Foreclosures and Short-Sales Spillover Effects from the Current Housing-Market Crash.” Economic Inquiry, 50(1), 217-31.

Fisher, Lynn M., Lauren Lambie-Hanson, and Paul Willen. 2013. "Foreclosure Externalities in Homeowner Associations: Evidence from Condominiums in Boston.” Working paper.

Gerardi, Kristopher, Eric Rosenblatt, Paul S. Willen and Vincent Yao. 2012.

“Foreclosure Externalities: Some New Evidence.” NBER Working Paper 18353.

Goodwyn, Wade. 2012. “Not So Neighborly Associations Foreclosing on Homes.” All Things Considered, National Public Radio. June 29, 2010.

Gordon, Tracy M. 2003. “Crowd Out or Crowd In?: The Effects of Common Interest Developments on Political Participation in California.” The Annals of Regional Science, 37(2): 203-233.

Gordon, Tracy M. 2004. "Moving Up by Moving Out? Planned Developments and Residential Segregation in California.” Urban Studies, 41(2): 441-461. 
Harding, J.P., E. Rosenblatt, and V.W. Yao. 2009. "The Contagion Effect of Foreclosed Properties.” Journal of Urban Economics, 66(3): 164-178.

Hartley, Daniel. 2010. "The Effect of Foreclosures on Nearby Housing Prices: Supply or Disamenity?” Federal Reserve Bank of Cleveland Working Paper 10-11.

Helsley, Robert W. and William C. Strange. 1998. “Private Government.” Journal of Public Economics, 69(2): 281-304.

Immergluck, Dan, Yun Sang Lee and Patrick Terranova. 2012, "Local Vacant Property Registration Ordinances in the U.S. An Analysis of Growth, Regional Trends, and Some Key Characteristics”, Working Paper.

Immergluck, Dan, and G. Smith. 2006. "The External Costs of Foreclosure: The Impact of Single-Family Mortgage Foreclosures on Property Values.” Housing Policy Debate, 17(1): 57-79.

Kobie, Timothy F., and Sugie Lee. 2011. "The Spatial-Temporal Impact of Residential Foreclosures on Single-Family Residential Property Values.” Urban Affairs Review, 47(1): 3-30.

Leonard, Tammy, and James C. Murdoch. 2009. "The neighborhood effects of foreclosure.” Journal of Geographic Systems, 11: 317-332.

Lin, Z., E. Rosenblatt, and V.W. Yao. 2009. "Spillover Effects of Foreclosures on Neighborhood Property Values.” The Journal of Real Estate Finance and Economics, 38(4): 387-407.

Lush, Tamara. 2011. "Homeowner associations foreclose on residents.” USA Today, July 9, 2011. Associated Press.

McCabe, Barbara Coyle and Jill Tao. 2006. "Private Governments and Private Services: Homeowners Associations in the City and Behind the Gate.” Review of Policy Research, 23(6): 1143-1157.

McKenzie, Evan. 2003. "Common-Interest Housing in the Communities of Tomorrow." Housing Policy Debate, 14(1\&2): 203-234.

Meltzer, Rachel. 2013. "Do Homeowners Associations Affect Citywide Segregation? Evidence from Florida Municipalities,” The New School working paper. 
Meltzer, Rachel, and Ron Cheung. 2013. "How Are Homeowners Associations Capitalized into Property Values?” Lincoln Institute of Land Policy Working Paper.

Nguyen, Ngoc. 2011. "Hard-Pressed Homeowners Facing Another Financial Threat.” New York Times, April 14, 2011.

Rogers, W.H., and W. Winter. 2009. “The Impact of Foreclosures on Neighboring Housing Sales.” Journal of Real Estate Research, 31(4): 455-479.

Schildt, Chris, Naomi Cytron, Elizabeth Kneebone, and Carolina Reid. 2013. “The Subprime Crisis in Suburbia: Exploring the Links Between Foreclosures and Suburban Poverty.” Federal Reserve Bank of San Francisco working paper \#2013-02.

Schuetz, J., V. Been, and I.G. Ellen. 2008. “Neighborhood Effects of Concentrated Mortgage Foreclosures.” Journal of Housing Economics, 17(4): 306-319.

Strahilevitz, Lior Jacob. 2006. "Exclusionary Amenities in Residential Communities.” Virginia Law Review, 92(3): 437-499.

Whitaker, Stephan and Thomas J. Fitzpatrick IV. 2011. “The Impact of Vacant, TaxDelinquent, and Foreclosed Property on Sales Prices of Neighboring Homes.” Federal Reserve Bank of Cleveland Working Paper 11-23R. 
Figure 1: Plot of Share of Homes in Zip Code in HOA against the Share of Homes that Are 90+ Days Delinquent

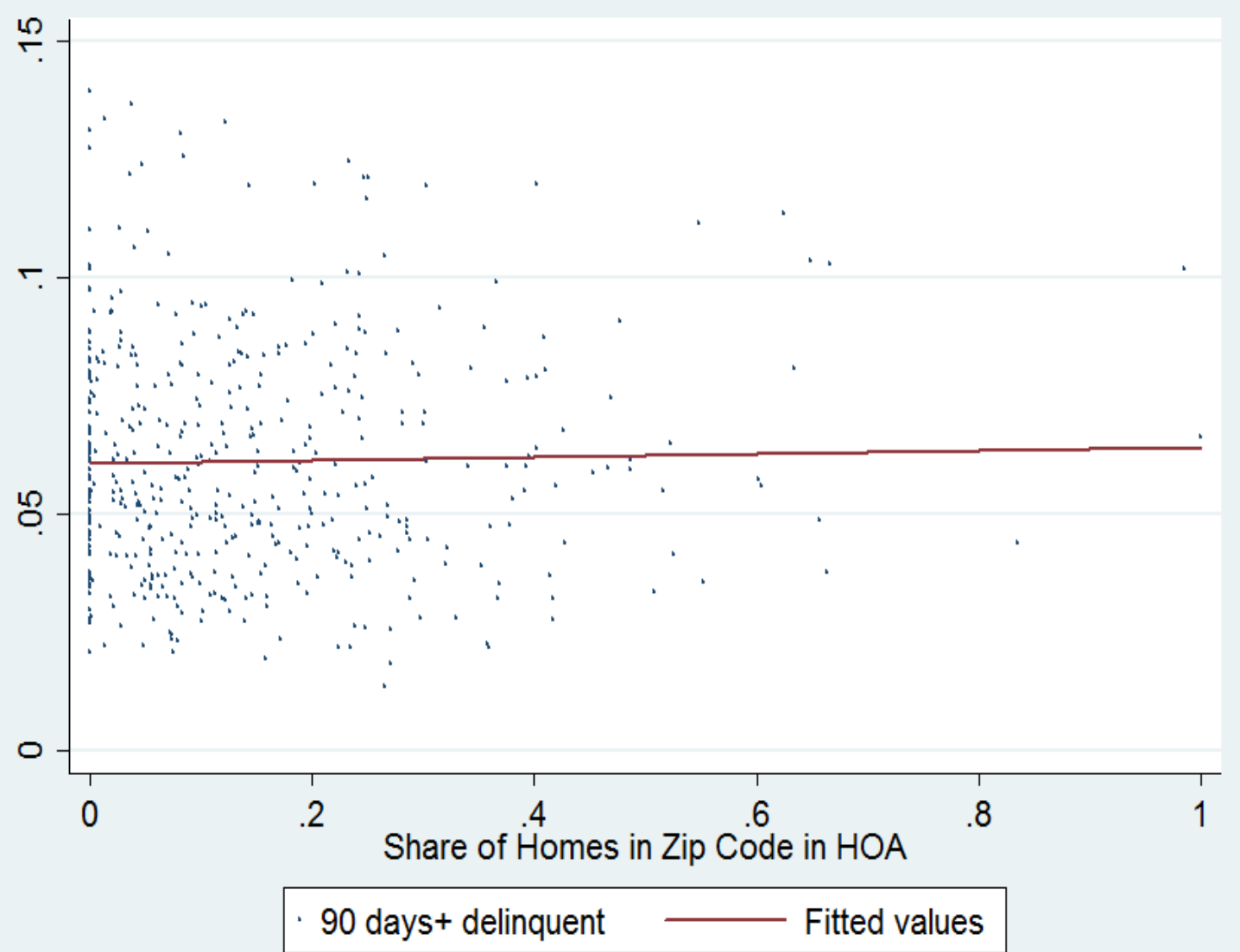


Figure 2: Spread of HOAs across Florida

1970

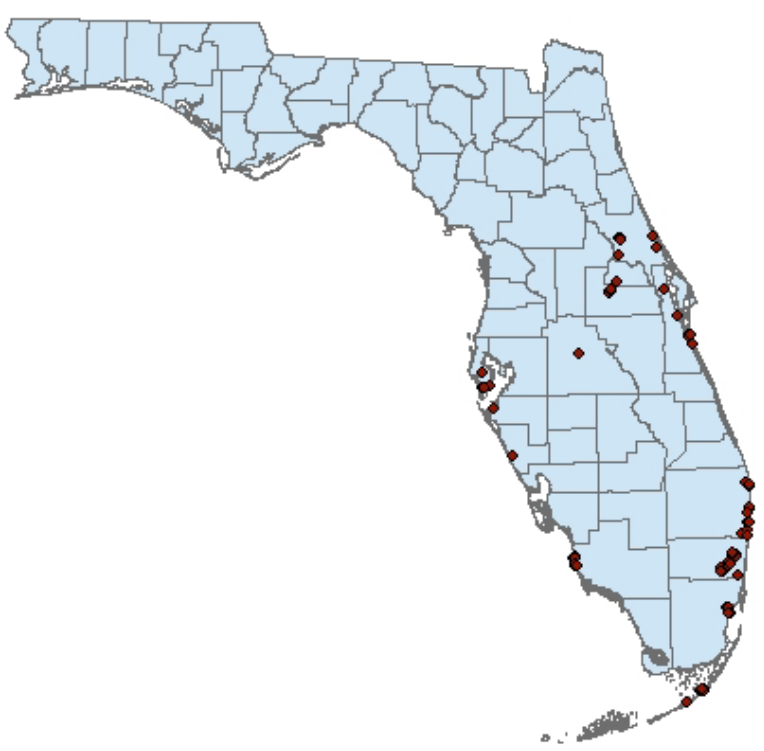

2008

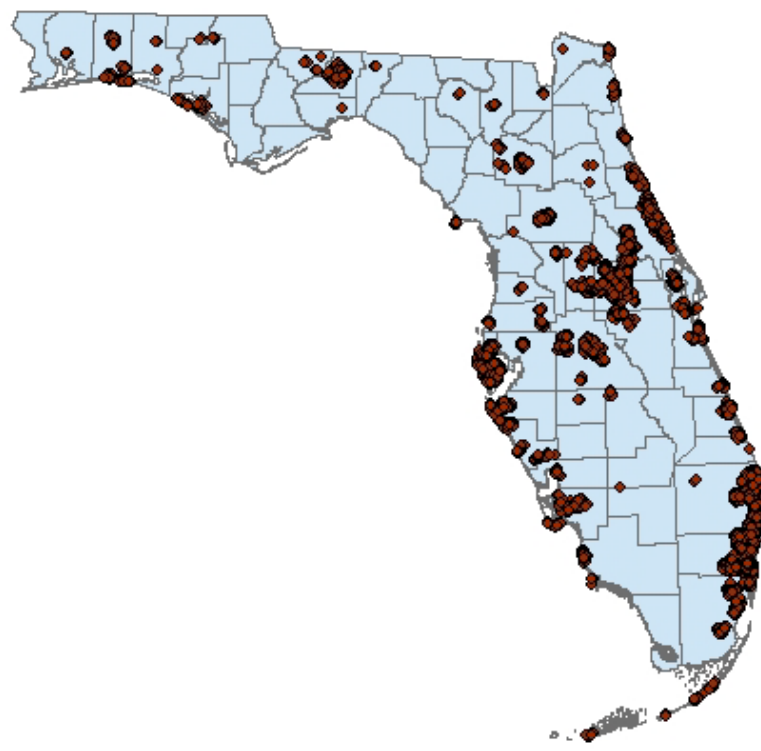


Table 1: Summary Statistics

\begin{tabular}{|c|c|c|c|c|}
\hline VARIABLES & $\begin{array}{c}(1) \\
\text { Full Sample } \\
\text { mean } \\
\text { (sd) }\end{array}$ & $\begin{array}{l}(2) \\
\text { HOA properties } \\
\text { mean } \\
(\mathrm{sd})\end{array}$ & $\begin{array}{c}\text { (3) } \\
\text { Non-HOA properties } \\
\text { mean } \\
(\mathrm{sd})\end{array}$ & $\begin{array}{c}(4) \\
\text { difference* } \\
(2)-(3)\end{array}$ \\
\hline $\ln ($ sales price/2008\$) & $\begin{array}{l}12.18 \\
(0.676)\end{array}$ & $\begin{array}{c}12.27 \\
(0.638)\end{array}$ & $\begin{array}{l}12.15 \\
(0.682)\end{array}$ & 0.12 \\
\hline lot size, in square feet & $\begin{array}{c}8.910 \\
(0.975)\end{array}$ & $\begin{array}{c}8.884 \\
(0.781)\end{array}$ & $\begin{array}{c}8.917 \\
(1.017)\end{array}$ & -0.033 \\
\hline quality of improvements & $\begin{array}{c}0.664 \\
(1.294)\end{array}$ & $\begin{array}{c}0.437 \\
(1.103)\end{array}$ & $\begin{array}{c}0.719 \\
(1.331)\end{array}$ & -0.282 \\
\hline year built & $\begin{array}{c}1992 \\
(12.85)\end{array}$ & $\begin{array}{c}1996 \\
(10.05)\end{array}$ & $\begin{array}{c}1991 \\
(13.25)\end{array}$ & 5 \\
\hline total living area & $\begin{array}{c}2,009 \\
(859.2)\end{array}$ & $\begin{array}{c}2,167 \\
(881.0)\end{array}$ & $\begin{array}{l}1,970 \\
(849.5)\end{array}$ & 197 \\
\hline number of units & $\begin{array}{l}1.049 \\
(0.292)\end{array}$ & $\begin{array}{l}1.031 \\
(0.221)\end{array}$ & $\begin{array}{l}1.053 \\
(0.306)\end{array}$ & -0.022 \\
\hline vacant & $\begin{array}{l}0.0510 \\
(0.220)\end{array}$ & $\begin{array}{l}0.0558 \\
(0.230)\end{array}$ & $\begin{array}{l}0.0498 \\
(0.218)\end{array}$ & 0.006 \\
\hline single family & $\begin{array}{c}0.952 \\
(0.214)\end{array}$ & $\begin{array}{c}0.973 \\
(0.162)\end{array}$ & $\begin{array}{c}0.947 \\
(0.225)\end{array}$ & 0.026 \\
\hline $\begin{array}{l}\text { share of homes in zip } \\
\text { code within an HOA }\end{array}$ & $\begin{array}{c}0.142 \\
(0.136)\end{array}$ & $\begin{array}{c}0.220 \\
(0.169)\end{array}$ & $\begin{array}{c}0.123 \\
(0.119)\end{array}$ & 0.097 \\
\hline \multicolumn{5}{|c|}{ Pre-normalized delinquency rates: } \\
\hline 30 days & $\begin{array}{c}0.0324 \\
(0.0141)\end{array}$ & $\begin{array}{c}0.0320 \\
(0.0132)\end{array}$ & $\begin{array}{c}0.0325 \\
(0.0143)\end{array}$ & -0.0005 \\
\hline 60 days & $\begin{array}{c}0.00955 \\
(0.00646)\end{array}$ & $\begin{array}{c}0.00941 \\
(0.00605)\end{array}$ & $\begin{array}{c}0.00959 \\
(0.00655)\end{array}$ & -0.00018 \\
\hline $90+$ days & $\begin{array}{c}0.0125 \\
(0.0113)\end{array}$ & $\begin{array}{c}0.0120 \\
(0.0105)\end{array}$ & $\begin{array}{c}0.0126 \\
(0.0114)\end{array}$ & -0.0006 \\
\hline in foreclosure & $\begin{array}{c}0.0118 \\
(0.0185)\end{array}$ & $\begin{array}{c}0.0115 \\
(0.0182)\end{array}$ & $\begin{array}{c}0.0119 \\
(0.0185)\end{array}$ & -0.0004 \\
\hline Observations & 316,616 & 61,669 & 254,947 & \\
\hline
\end{tabular}

*All differences are statistically different from zero at 1 percent level, assuming unequal variances in the HOA and non-HOA samples.

Note: quality of improvements is measured on 1-6 scale, ranging from minimum to superior; delinquency is measured as the share of all loans that were delinquent in the properties' zip code in the month of sale as recorded in the LPS and CoreLogic mortgage databases. In the regressions below, the delinquency rate is standardized to facilitate comparison across different durations of delinquency. 
Table 2: Baseline specification

\begin{tabular}{lccc}
\hline Dep. Var. = Log sales price & $(1)$ & $(2)$ & $(3)$ \\
VARIABLES & just delinquency & just HOA & HOA and delinquency \\
\hline \multirow{2}{*}{ delinquency (30 days) } & $-0.147^{* * *}$ & & $-0.149^{* * *}$ \\
& $(0.0109)$ & & $(0.0112)$ \\
HOA & & $0.0233^{* *}$ & $0.0228^{* * *}$ \\
& & $(0.00990)$ & $(0.00879)$ \\
HOA*Delinquency & & $0.0153^{*}$ \\
& & & $(0.00817)$ \\
ln(lot size) & $0.0304^{* * *}$ & $0.0206^{* *}$ & $0.0311^{* * *}$ \\
& $(0.0100)$ & $(0.0104)$ & $(0.0101)$ \\
quality of improvements & 0.0377 & $0.0457^{*}$ & 0.0381 \\
& $(0.0237)$ & $(0.0271)$ & $(0.0236)$ \\
year built & $0.00220^{* * *}$ & $0.00186^{* *}$ & $0.00211^{* * *}$ \\
& $(0.000748)$ & $(0.000936)$ & $(0.000753)$ \\
ln(total living area) & $0.000402^{* * *}$ & $0.000436^{* * *}$ & $0.000401^{* * *}$ \\
& $(1.46 \mathrm{e}-05)$ & $(1.57 \mathrm{e}-05)$ & $(1.46 \mathrm{e}-05)$ \\
number of units on parcel & 0.0142 & 0.0152 & 0.0152 \\
& $(0.0124)$ & $(0.0156)$ & $(0.0124)$ \\
vacant & $-1.501^{* * *}$ & $-1.526^{* * *}$ & $-1.500^{* * *}$ \\
& $(0.0366)$ & $(0.0381)$ & $(0.0366)$ \\
single family & 0.0177 & $-9.20 \mathrm{e}-06$ & 0.0144 \\
& $(0.0477)$ & $(0.0498)$ & $(0.0479)$ \\
share of homes in zip & -0.0736 & -0.00996 & -0.0896 \\
code within an HOA & $(0.0745)$ & $(0.102)$ & $(0.0749)$ \\
Constant & $6.744^{* * *}$ & $7.447^{* * *}$ & $6.930^{* * *}$ \\
& $(1.515)$ & $(1.887)$ & $(1.525)$ \\
\hline Observations & 316,267 & 316,267 & 316,267 \\
R-squared & 0.745 & 0.714 & 0.745 \\
\hline Standard errors, clustered by zip code, in parentheses; *** $\mathrm{p}<0.01, * * \mathrm{p}<0.05, * 0.1$ \\
Note: delinquency is at 30 days. Specification includes county-year fixed effects. & \\
& & &
\end{tabular}


Table 3: Duration of Delinquency and HOA status

\begin{tabular}{lcccc}
\hline Dep. Var. = Log sales price & $(1)$ & $(2)$ & $(3)$ & $(4)$ \\
VARIABLES & delinq: 30 days & delinq: 60 days & delinq: $90+$ days & foreclosure \\
\hline delinquency & $-0.149^{* * *}$ & $-0.139 * * *$ & $-0.162^{* * *}$ & $-0.139^{* * *}$ \\
& $(0.0112)$ & $(0.0103)$ & $(0.0127)$ & $(0.0128)$ \\
HOA & $0.0228^{* * *}$ & $0.0220^{* *}$ & $0.0203^{* *}$ & $0.0218^{* *}$ \\
& $(0.00879)$ & $(0.00906)$ & $(0.00915)$ & $(0.00965)$ \\
HOA*Delinquency & $0.0153^{*}$ & 0.00104 & -0.00176 & 0.00348 \\
& $(0.00817)$ & $(0.00663)$ & $(0.00585)$ & $(0.00502)$ \\
ln(lot size) & $0.0311^{* * *}$ & $0.0283^{* * *}$ & $0.0284^{* * *}$ & $0.0231^{* *}$ \\
& $(0.0101)$ & $(0.01000)$ & $(0.0100)$ & $(0.00996)$ \\
quality of improvements & 0.0381 & $0.0423^{*}$ & 0.0414 & $0.0457^{*}$ \\
& $(0.0236)$ & $(0.0249)$ & $(0.0252)$ & $(0.0263)$ \\
year built & $0.00211^{* * *}$ & $0.00220^{* * *}$ & $0.00228 * * *$ & $0.00208^{* *}$ \\
& $(0.000753)$ & $(0.000791)$ & $(0.000800)$ & $(0.000868)$ \\
total living area & $0.000401^{* * *}$ & $0.000413^{* * *}$ & $0.000414^{* * *}$ & $0.000427^{* * *}$ \\
number of units on parcel & $(1.46 \mathrm{e}-05)$ & $(1.48 \mathrm{e}-05)$ & $(1.49 \mathrm{e}-05)$ & $(1.53 \mathrm{e}-05)$ \\
& 0.0152 & 0.0145 & 0.0156 & 0.0173 \\
vacant & $(0.0124)$ & $(0.0135)$ & $(0.0133)$ & $(0.0148)$ \\
& $-1.500^{* * *}$ & $-1.511^{* * *}$ & $-1.513^{* * *}$ & $-1.524^{* * *}$ \\
single family & $(0.0366)$ & $(0.0372)$ & $(0.0371)$ & $(0.0378)$ \\
& 0.0144 & 0.00492 & 0.0120 & 0.000768 \\
share of homes in zip & $(0.0479)$ & $(0.0478)$ & $(0.0476)$ & $(0.0487)$ \\
code within an HOA & -0.0896 & -0.0573 & -0.0597 & -0.0409 \\
Constant & $(0.0749)$ & $(0.0812)$ & $(0.0827)$ & $(0.0945)$ \\
& $6.930^{* * *}$ & $6.740^{* * *}$ & $6.585^{* * *}$ & $6.991^{* * *}$ \\
& $(1.525)$ & $(1.598)$ & $(1.616)$ & $(1.751)$ \\
Observations & & & & 316,267 \\
R-squared & 316,267 & 316,267 & 316,267 & 0.725 \\
\hline San & 0.745 & 0.736 & 0.738 &
\end{tabular}

Standard errors, clustered by zip code, in parentheses; ${ }^{* * *} \mathrm{p}<0.01$, ${ }^{* *} \mathrm{p}<0.05,{ }^{*} \mathrm{p}<0.1$

Note: county-year fixed effects were included. 


\section{Table 4: Delinquency and HOA age}

\begin{tabular}{|c|c|c|c|c|}
\hline $\begin{array}{l}\text { Dep. Var. = Log sales price } \\
\text { VARIABLES }\end{array}$ & $\begin{array}{c}(1) \\
\text { delinq: } 30 \text { days }\end{array}$ & $\begin{array}{c}(2) \\
\text { delinq: } 60 \text { days }\end{array}$ & $\begin{array}{c}(3) \\
\text { delinq: } 90+\text { days }\end{array}$ & $\begin{array}{c}\text { (4) } \\
\text { delinq: foreclosure }\end{array}$ \\
\hline delinquency & $\begin{array}{c}-0.182 * * * \\
(0.0216)\end{array}$ & $\begin{array}{c}-0.148^{* * *} \\
(0.0182)\end{array}$ & $\begin{array}{c}-0.172^{* * *} \\
(0.0179)\end{array}$ & $\begin{array}{c}-0.151^{* * *} \\
(0.0158)\end{array}$ \\
\hline HOA & $\begin{array}{l}0.0226 * * * \\
(0.00870)\end{array}$ & $\begin{array}{l}0.0221^{* *} \\
(0.00903)\end{array}$ & $\begin{array}{l}0.0206^{* *} \\
(0.00910)\end{array}$ & $\begin{array}{l}0.0222^{* *} \\
(0.00958)\end{array}$ \\
\hline HOA*Delinquency & $\begin{array}{l}0.0339 * * \\
(0.0158)\end{array}$ & $\begin{array}{l}0.00896 \\
(0.0132)\end{array}$ & $\begin{array}{l}0.00837 \\
(0.0121)\end{array}$ & $\begin{array}{c}0.0119 \\
(0.0121)\end{array}$ \\
\hline $\begin{array}{l}\text { (HOA less than } 5 \text { yrs old) } \\
\text { *delinquency }\end{array}$ & $0.0332 *$ & 0.00907 & 0.0104 & 0.0118 \\
\hline & $(0.0202)$ & $(0.0163)$ & $(0.0150)$ & $(0.0133)$ \\
\hline $\begin{array}{l}\text { (HOA 5-15 yrs old) } \\
\text { *delinquency }\end{array}$ & 0.00961 & -0.00432 & -0.00687 & 0.00110 \\
\hline & $(0.0138)$ & $(0.0121)$ & $(0.0109)$ & $(0.00732)$ \\
\hline HOA less than 5 yrs old & $\begin{array}{c}0.0512^{* *} \\
(0.0210)\end{array}$ & $\begin{array}{c}0.0558 * * \\
(0.0220)\end{array}$ & $\begin{array}{c}0.0551^{* *} \\
(0.0223)\end{array}$ & $\begin{array}{c}0.0579 * * \\
(0.0236)\end{array}$ \\
\hline HOA 5-15 yrs old & $\begin{array}{c}0.0643 * * * \\
(0.0139)\end{array}$ & $\begin{array}{c}0.0703^{* * *} \\
(0.0148)\end{array}$ & $\begin{array}{c}0.0717^{* * * *} \\
(0.0149)\end{array}$ & $\begin{array}{c}0.0781 * * * \\
(0.0156)\end{array}$ \\
\hline $\ln ($ lot size $)$ & $\begin{array}{c}0.0310 * * * \\
(0.0101)\end{array}$ & $\begin{array}{c}0.0283^{* * *} \\
(0.01000)\end{array}$ & $\begin{array}{c}0.0283^{* * *} \\
(0.0100)\end{array}$ & $\begin{array}{l}0.0231^{* *} \\
(0.00997)\end{array}$ \\
\hline quality of improvements & $\begin{array}{c}0.0380 \\
(0.0236)\end{array}$ & $\begin{array}{l}0.0423^{*} \\
(0.0249)\end{array}$ & $\begin{array}{c}0.0415 \\
(0.0252)\end{array}$ & $\begin{array}{l}0.0457 * \\
(0.0263)\end{array}$ \\
\hline year built & $\begin{array}{l}0.00210^{* * *} \\
(0.000752)\end{array}$ & $\begin{array}{l}0.00220^{* * *} \\
(0.000791)\end{array}$ & $\begin{array}{c}0.00228^{* * *} \\
(0.000800)\end{array}$ & $\begin{array}{l}0.00209 * * \\
(0.000868)\end{array}$ \\
\hline total living area & $\begin{array}{l}0.000401^{* * *} \\
(1.46 \mathrm{e}-05)\end{array}$ & $\begin{array}{l}0.000413^{* * *} \\
(1.48 \mathrm{e}-05)\end{array}$ & $\begin{array}{c}0.000414 * * * \\
(1.49 \mathrm{e}-05)\end{array}$ & $\begin{array}{c}0.000427^{* * *} \\
(1.53 \mathrm{e}-05)\end{array}$ \\
\hline number of units on parcel & $\begin{array}{c}0.0154 \\
(0.0124)\end{array}$ & $\begin{array}{c}0.0145 \\
(0.0135)\end{array}$ & $\begin{array}{c}0.0156 \\
(0.0133)\end{array}$ & $\begin{array}{c}0.0173 \\
(0.0148)\end{array}$ \\
\hline vacant & $\begin{array}{l}-1.499 * * * \\
(0.0365)\end{array}$ & $\begin{array}{c}-1.511^{* * *} \\
(0.0372)\end{array}$ & $\begin{array}{c}-1.513^{* * *} \\
(0.0371)\end{array}$ & $\begin{array}{c}-1.524 * * * \\
(0.0378)\end{array}$ \\
\hline single family & $\begin{array}{c}0.0150 \\
(0.0479)\end{array}$ & $\begin{array}{l}0.00509 \\
(0.0479)\end{array}$ & $\begin{array}{c}0.0121 \\
(0.0476)\end{array}$ & $\begin{array}{c}0.000853 \\
(0.0487)\end{array}$ \\
\hline $\begin{array}{l}\text { share of homes in zip } \\
\text { code within an HOA }\end{array}$ & $\begin{array}{l}-0.0904 \\
(0.0749)\end{array}$ & $\begin{array}{l}-0.0574 \\
(0.0812)\end{array}$ & $\begin{array}{l}-0.0599 \\
(0.0827)\end{array}$ & $\begin{array}{l}-0.0410 \\
(0.0945)\end{array}$ \\
\hline Constant & $\begin{array}{c}7.286 * * * \\
(1.551)\end{array}$ & $\begin{array}{c}7.095^{* * * *} \\
(1.628)\end{array}$ & $\begin{array}{c}6.942 * * * \\
(1.645)\end{array}$ & $\begin{array}{c}7.349 * * * \\
(1.780)\end{array}$ \\
\hline Observations & 316,267 & 316,267 & 316,267 & 316,267 \\
\hline R-squared & 0.746 & 0.737 & 0.739 & 0.725 \\
\hline
\end{tabular}

Standard errors, clustered by zip code, in parentheses; ${ }^{* * *} \mathrm{p}<0.01,{ }^{* *} \mathrm{p}<0.05,{ }^{*} \mathrm{p}<0.1$. Note: county-year fixed effects were included. 
Table 5: Delinquency and HOA size

\begin{tabular}{|c|c|c|c|c|}
\hline $\begin{array}{l}\text { Dep. Var. = Log sales price } \\
\text { VARIABLES }\end{array}$ & $\begin{array}{c}\text { (1) } \\
\text { delinq: } 30 \text { days }\end{array}$ & $\begin{array}{c}\text { (2) } \\
\text { delinq: } 60 \text { days }\end{array}$ & $\begin{array}{c}\text { (3) } \\
\text { delinq: } 90+\text { days }\end{array}$ & $\begin{array}{c}\text { (4) } \\
\text { delinq: foreclosure }\end{array}$ \\
\hline delinquency & $\begin{array}{c}-0.149 * * * \\
(0.0112)\end{array}$ & $\begin{array}{l}2.72 \mathrm{e}-05^{* * *} \\
(6.12 \mathrm{e}-06)\end{array}$ & $\begin{array}{c}-0.161^{* * *} \\
(0.0127)\end{array}$ & $\begin{array}{c}-0.138 * * * \\
(0.0129)\end{array}$ \\
\hline HOA & $\begin{array}{c}0.0378 * * * \\
(0.0105)\end{array}$ & $\begin{array}{c}0.0379 * * * \\
(0.0109)\end{array}$ & $\begin{array}{c}0.0370 * * * \\
(0.0112)\end{array}$ & $\begin{array}{l}0.0415^{* * *} \\
(0.0120)\end{array}$ \\
\hline HOA size (units) & $\begin{array}{c}-3.86 \mathrm{e}-05 * * * \\
(9.48 \mathrm{e}-06)\end{array}$ & $\begin{array}{l}-4.04 \mathrm{e}-05^{* * *} \\
(1.04 \mathrm{e}-05)\end{array}$ & $\begin{array}{l}-4.00 \mathrm{e}-05 * * * \\
(1.08 \mathrm{e}-05)\end{array}$ & $\begin{array}{l}-4.63 \mathrm{e}-05^{* * *} \\
(1.22 \mathrm{e}-05)\end{array}$ \\
\hline HOA*Delinquency & $\begin{array}{c}0.0153^{*} \\
(0.00817)\end{array}$ & $\begin{array}{c}0.00104 \\
(0.00663)\end{array}$ & $\begin{array}{l}-0.00176 \\
(0.00585)\end{array}$ & $\begin{array}{c}0.00348 \\
(0.00502)\end{array}$ \\
\hline HOA size*Delinquency & $\begin{array}{l}2.78 \mathrm{e}-05^{* * *} \\
(7.39 \mathrm{e}-06)\end{array}$ & $\begin{array}{c}-0.0102 \\
(0.00795)\end{array}$ & $\begin{array}{l}2.11 \mathrm{e}-05^{* * *} \\
(6.46 \mathrm{e}-06)\end{array}$ & $\begin{array}{c}1.42 \mathrm{e}-05^{* * *} \\
(4.84 \mathrm{e}-06)\end{array}$ \\
\hline $\ln ($ lot size) & $\begin{array}{c}0.0318 * * * \\
(0.0102)\end{array}$ & $\begin{array}{c}0.0291 * * * \\
(0.0101)\end{array}$ & $\begin{array}{c}0.0293 * * * \\
(0.0101)\end{array}$ & $\begin{array}{c}0.0241 * * \\
(0.0100)\end{array}$ \\
\hline quality of improvements & $\begin{array}{c}0.0383 \\
(0.0237)\end{array}$ & $\begin{array}{l}0.0426^{*} \\
(0.0249)\end{array}$ & $\begin{array}{l}0.0418^{*} \\
(0.0253)\end{array}$ & $\begin{array}{l}0.0461^{*} \\
(0.0263)\end{array}$ \\
\hline year built & $\begin{array}{l}0.00210^{* * *} \\
(0.000753)\end{array}$ & $\begin{array}{l}0.00219 * * * \\
(0.000790)\end{array}$ & $\begin{array}{l}0.00226 * * * \\
(0.000799)\end{array}$ & $\begin{array}{l}0.00206^{* *} \\
(0.000866)\end{array}$ \\
\hline total living area & $\begin{array}{c}0.000401 * * * \\
(1.45 \mathrm{e}-05)\end{array}$ & $\begin{array}{l}0.000412 * * * \\
(1.48 \mathrm{e}-05)\end{array}$ & $\begin{array}{l}0.000413 * * * \\
(1.49 \mathrm{e}-05)\end{array}$ & $\begin{array}{c}0.000426 * * * \\
(1.53 \mathrm{e}-05)\end{array}$ \\
\hline number of units on parcel & $\begin{array}{c}0.0156 \\
(0.0124)\end{array}$ & $\begin{array}{c}0.0149 \\
(0.0135)\end{array}$ & $\begin{array}{c}0.0162 \\
(0.0133)\end{array}$ & $\begin{array}{c}0.0180 \\
(0.0148)\end{array}$ \\
\hline vacant & $\begin{array}{c}-1.499 * * * \\
(0.0365)\end{array}$ & $\begin{array}{c}-1.510 * * * \\
(0.0371)\end{array}$ & $\begin{array}{c}-1.512^{* * *} \\
(0.0370)\end{array}$ & $\begin{array}{c}-1.523^{* * *} \\
(0.0376)\end{array}$ \\
\hline single Family & $\begin{array}{c}0.0123 \\
(0.0481)\end{array}$ & $\begin{array}{l}0.00276 \\
(0.0481)\end{array}$ & $\begin{array}{l}0.00949 \\
(0.0479)\end{array}$ & $\begin{array}{l}-0.00215 \\
(0.0489)\end{array}$ \\
\hline $\begin{array}{l}\text { share of homes in zip } \\
\text { code within an HOA }\end{array}$ & $\begin{array}{l}-0.0882 \\
(0.0748)\end{array}$ & $\begin{array}{l}-0.0557 \\
(0.0811)\end{array}$ & $\begin{array}{c}-0.0588 \\
(0.0827)\end{array}$ & $\begin{array}{l}-0.0401 \\
(0.0946)\end{array}$ \\
\hline Constant & $\begin{array}{c}6.941 * * * \\
(1.524)\end{array}$ & $\begin{array}{c}6.762 * * * \\
(1.597)\end{array}$ & $\begin{array}{c}6.614 * * * \\
(1.615)\end{array}$ & $\begin{array}{c}7.034^{* * * *} \\
(1.748)\end{array}$ \\
\hline Observations & 316,267 & 316,267 & 316,267 & 316,267 \\
\hline R-squared & 0.746 & 0.737 & 0.739 & 0.725 \\
\hline
\end{tabular}

Standard errors, clustered by zip code, in parentheses; ${ }^{* * *} \mathrm{p}<0.01,{ }^{* *} \mathrm{p}<0.05,{ }^{*} \mathrm{p}<0.1$

Note: county-year fixed effects were included. 


\section{Table 6: Delinquency and Spillovers}

\begin{tabular}{|c|c|c|c|c|}
\hline $\begin{array}{l}\text { Dep. Var. = Log sales price } \\
\text { VARIABLES }\end{array}$ & $\begin{array}{c}(1) \\
\text { delinq: } 30 \text { days }\end{array}$ & $\begin{array}{c}(2) \\
\text { delinq: } 60 \text { days }\end{array}$ & $\begin{array}{c}(3) \\
\text { delinq: } 90+\text { days }\end{array}$ & $\begin{array}{c}\text { (4) } \\
\text { delinq: foreclosure }\end{array}$ \\
\hline delinquency & $\begin{array}{c}-0.124^{* * *} \\
(0.0173)\end{array}$ & $\begin{array}{c}-0.0983^{* * *} \\
(0.0140)\end{array}$ & $\begin{array}{c}-0.129 * * * \\
(0.0178)\end{array}$ & $\begin{array}{c}-0.119^{* * *} \\
(0.0156)\end{array}$ \\
\hline HOA & $\begin{array}{l}0.0215^{* *} \\
(0.00864)\end{array}$ & $\begin{array}{l}0.0217 * * \\
(0.00901)\end{array}$ & $\begin{array}{l}0.0204 * * \\
(0.00914)\end{array}$ & $\begin{array}{l}0.0211^{* *} \\
(0.00956)\end{array}$ \\
\hline HOA spillover (2mi) & $\begin{array}{c}0.000275 \\
(0.0562)\end{array}$ & $\begin{array}{c}0.0200 \\
(0.0603)\end{array}$ & $\begin{array}{c}0.0128 \\
(0.0599)\end{array}$ & $\begin{array}{c}0.0307 \\
(0.0606)\end{array}$ \\
\hline HOA*Delinquency & $\begin{array}{l}0.0157 * * \\
(0.00798)\end{array}$ & $\begin{array}{c}0.00205 \\
(0.00619)\end{array}$ & $\begin{array}{l}-0.00113 \\
(0.00527)\end{array}$ & $\begin{array}{c}0.00312 \\
(0.00444)\end{array}$ \\
\hline HOA spillover*Delinquency & $\begin{array}{l}-0.0252 \\
(0.0193)\end{array}$ & $\begin{array}{c}-0.0376^{* *} \\
(0.0161)\end{array}$ & $\begin{array}{l}-0.0185 \\
(0.0191)\end{array}$ & $\begin{array}{l}-0.00343 \\
(0.0165)\end{array}$ \\
\hline $\ln ($ lot size) & $\begin{array}{c}0.0311^{* * *} \\
(0.0101)\end{array}$ & $\begin{array}{l}0.0285^{* * *} \\
(0.01000)\end{array}$ & $\begin{array}{c}0.0284 * * * \\
(0.0101)\end{array}$ & $\begin{array}{l}0.0232 * * \\
(0.00997)\end{array}$ \\
\hline quality of improvements & $\begin{array}{c}0.0379 \\
(0.0236)\end{array}$ & $\begin{array}{l}0.0422^{*} \\
(0.0248)\end{array}$ & $\begin{array}{c}0.0414 \\
(0.0252)\end{array}$ & $\begin{array}{l}0.0458 * \\
(0.0263)\end{array}$ \\
\hline year built & $\begin{array}{l}0.00210 * * * \\
(0.000741)\end{array}$ & $\begin{array}{l}0.00221^{* * * *} \\
(0.000775)\end{array}$ & $\begin{array}{l}0.00228 * * * \\
(0.000787)\end{array}$ & $\begin{array}{l}0.00212^{* *} \\
(0.000852)\end{array}$ \\
\hline total living area & $\begin{array}{l}0.000401^{* * *} \\
(1.45 \mathrm{e}-05)\end{array}$ & $\begin{array}{c}0.000413 * * * \\
(1.48 \mathrm{e}-05)\end{array}$ & $\begin{array}{c}0.000414^{* * *} \\
(1.49 \mathrm{e}-05)\end{array}$ & $\begin{array}{c}0.000427 * * * \\
(1.53 \mathrm{e}-05)\end{array}$ \\
\hline number of units on parcel & $\begin{array}{c}0.0141 \\
(0.0123)\end{array}$ & $\begin{array}{c}0.0136 \\
(0.0134)\end{array}$ & $\begin{array}{c}0.0154 \\
(0.0132)\end{array}$ & $\begin{array}{c}0.0175 \\
(0.0148)\end{array}$ \\
\hline vacant & $\begin{array}{c}-1.499 * * * \\
(0.0366)\end{array}$ & $\begin{array}{c}-1.510 * * * \\
(0.0372)\end{array}$ & $\begin{array}{c}-1.513 * * * \\
(0.0371)\end{array}$ & $\begin{array}{c}-1.524 * * * \\
(0.0378)\end{array}$ \\
\hline single family & $\begin{array}{c}0.0149 \\
(0.0480)\end{array}$ & $\begin{array}{l}0.00495 \\
(0.0479)\end{array}$ & $\begin{array}{c}0.0121 \\
(0.0476)\end{array}$ & $\begin{array}{l}0.000479 \\
(0.0487)\end{array}$ \\
\hline $\begin{array}{l}\text { share of homes in zip } \\
\text { code within an HOA }\end{array}$ & $\begin{array}{l}-0.0867 \\
(0.0743)\end{array}$ & $\begin{array}{l}-0.0556 \\
(0.0802)\end{array}$ & $\begin{array}{l}-0.0594 \\
(0.0822)\end{array}$ & $\begin{array}{l}-0.0442 \\
(0.0943)\end{array}$ \\
\hline Constant & $\begin{array}{c}6.951 * * * \\
(1.494)\end{array}$ & $\begin{array}{c}6.720 * * * \\
(1.559)\end{array}$ & $\begin{array}{c}6.582 * * * \\
(1.585)\end{array}$ & $\begin{array}{c}6.915^{* * *} \\
(1.714)\end{array}$ \\
\hline Observations & 316,267 & 316,267 & 316,267 & 316,267 \\
\hline R-squared & 0.745 & 0.737 & 0.738 & 0.725 \\
\hline
\end{tabular}

Standard errors, clustered by zip code, in parentheses; ${ }^{* * *} \mathrm{p}<0.01$, ${ }^{* *} \mathrm{p}<0.05,{ }^{*} \mathrm{p}<0.1$

Note: county-year fixed effects. 


\section{Appendix Tables}

Table A1: Alternative fixed effects and measures of delinquency: City Fixed Effects

\begin{tabular}{|c|c|c|c|c|}
\hline $\begin{array}{l}\text { Dep. Var. = Log sales price } \\
\text { VARIABLES }\end{array}$ & $\begin{array}{c}\text { (1) } \\
30 \text { days delinquent }\end{array}$ & $\begin{array}{c}(2) \\
60 \text { days delinquent }\end{array}$ & $\begin{array}{c}\text { (3) } \\
90 \text { days delinquent }\end{array}$ & $\begin{array}{c}(4) \\
\text { Share of mortgages } \\
\text { in foreclosure }\end{array}$ \\
\hline Delinquency & $\begin{array}{c}-0.0829 * * * \\
(0.00807)\end{array}$ & $\begin{array}{c}-0.0700 * * * \\
(0.00802)\end{array}$ & $\begin{array}{c}-0.0857 * * * \\
(0.00915)\end{array}$ & $\begin{array}{c}-0.0693 * * * \\
(0.0114)\end{array}$ \\
\hline $\mathrm{HOA}$ & $\begin{array}{l}0.0170 * * \\
(0.00760)\end{array}$ & $\begin{array}{l}0.0166 * * \\
(0.00784)\end{array}$ & $\begin{array}{c}0.0156^{*} \\
(0.00797)\end{array}$ & $\begin{array}{l}0.0166 * * \\
(0.00803)\end{array}$ \\
\hline HOA*Delinquency & $\begin{array}{c}0.0116^{*} \\
(0.00685)\end{array}$ & $\begin{array}{l}-0.00139 \\
(0.00550)\end{array}$ & $\begin{array}{l}-0.00401 \\
(0.00476)\end{array}$ & $\begin{array}{l}-0.00357 \\
(0.00522)\end{array}$ \\
\hline Observations & 316,267 & 316,267 & 316,267 & 316,267 \\
\hline R-squared & 0.789 & 0.786 & 0.788 & 0.785 \\
\hline
\end{tabular}

Standard errors, clustered by zip code, in parentheses; *** $\mathrm{p}<0.01,{ }^{* *} \mathrm{p}<0.05,{ }^{*} \mathrm{p}<0.1$

Note: contains all housing and neighborhood quality measures included in the baseline specification in

Table 2. The specification includes city fixed effects and year dummies, but they are not interacted.

\section{Table A2: Alternative fixed effects and measures of delinquency: Zip Code Fixed Effects}

\begin{tabular}{|c|c|c|c|c|}
\hline Dep. Var. = Log sales price & (1) & (2) & (3) & (4) \\
\hline VARIABLES & 30 days delinquent & 60 days delinquent & 90 days delinquent & $\begin{array}{c}\text { Share of mortgages } \\
\text { in foreclosure }\end{array}$ \\
\hline Delinquency & $\begin{array}{c}-0.0290 * * * \\
(0.00674)\end{array}$ & $\begin{array}{c}-0.0192 * * * \\
(0.00638)\end{array}$ & $\begin{array}{c}-0.0443 * * * \\
(0.00963)\end{array}$ & $\begin{array}{c}-0.0413 * * * \\
(0.0105)\end{array}$ \\
\hline $\mathrm{HOA}$ & $\begin{array}{l}0.0251^{* * *} \\
(0.00750)\end{array}$ & $\begin{array}{l}0.0246 * * * \\
(0.00776)\end{array}$ & $\begin{array}{l}0.0240 * * * \\
(0.00781)\end{array}$ & $\begin{array}{l}0.0241^{* * *} \\
(0.00788)\end{array}$ \\
\hline HOA*Delinquency & $\begin{array}{l}0.0125^{* *} \\
(0.00531)\end{array}$ & $\begin{array}{l}-0.00293 \\
(0.00454)\end{array}$ & $\begin{array}{l}-0.00510 \\
(0.00410)\end{array}$ & $\begin{array}{l}-0.00811^{*} \\
(0.00478)\end{array}$ \\
\hline Observations & 316,267 & 316,267 & 316,267 & 316,267 \\
\hline R-squared & 0.804 & 0.804 & 0.805 & 0.805 \\
\hline
\end{tabular}

Note: contains all housing and neighborhood quality measures included in the baseline specification in Table 2. The specification includes zip code fixed effects and year dummies, but they are not interacted. 